\title{
МИСТЕЦТВО СЛОВА В МЕДИЦИНІ
}

\author{
O. I. Боєва
}

КЗ «Павлоградська міська лікарня № 1 дОР»

\begin{abstract}
Деонтологічні вимоги до культури слова полягають в тому, що медичний працівник повинен вміти: розповісти хворому про хворобу та їі лікування; заспокоїти і підбадьорити хворого; використовувати слово як важливий фактор психотерапії; вживати слово так, щоб воно стало свідченням загальної та медичної культури; переконати хворого в необхідності того чи іншого лікування; терпляче мовчати, коли цього вимагають інтереси хворого; не позбавляти хворого надії на одужання; володіти собою в усіх ситуаціях.
\end{abstract}

\section{ART OF SPEECH IN MEDICINE}

\section{O. I. Boyeva}

\section{Municipal Institution «Pavlohrad City Hospital № 1 of Dnipropetrovsk Regional Counsil»}

Deontological requirements for culture of speech of medical professional require that personnel must be able: to tell the patient about the disease and its treatment; reassure and encourage the patient; use the word as an important factor of psychotherapy; use the word so that it was evidence of general and health culture; convince a patient in need of a treatment; patiently be silent when the interests of the patient; not to deprive the patient hope of recovery; possess oneself in all situations.

Вступ. Етика - це наука, вчення про мораль і моральність. Медична деонтологія - частина медичної етики; сукупність необхідних етичних норм і приписів для медичних працівників у здійсненні професійної діяльності. Деонтологія вивчає моральний зміст дій і вчинків медичного персоналу в конкретній ситуації. Теоретичною основою деонтології $\epsilon$ медична етика, а деонтологія, проявляючись у вчинках медичного персоналу, являє собою практичне застосування медико-етичних принципів. Тому важливим $\epsilon$ дослідження медичної етики, а саме - психоемоційної сторони діяльності медичних працівників. Вивчення принципів поведінки медичного персоналу спрямоване на підвищення ефективності лікування [1, 2].

Основна частина. Аспектами медичної деонтології вважали взаємини:

- медпрацівників з хворим;

- медичних працівників з родичами хворого;

- медпрацівників між собою.

Актуальним питанням на сьогодні є спілкування медпрацівника і хворого. Багатьом із нас доводилося бувати в лікарні, поліклініці або в будь-якому лікувальному закладі, де кожен з нас спілкувався з лікарем

(c) О. І. Боєва, 2016 або медсестрою [2]. Але чи замислювався хто-небудь, наскільки це спілкування впливає на нас, а точніше на перебіг нашого захворювання, і яким чином медпрацівник може поліпшити наш стан? Звичайно, можна сказати, що все залежить від ліків, які нам призначає лікар і видає медсестра, від лікувальних процедур, які призначаються лікарем, але це ще не все, що необхідно для повного одужання. Найголовніше - це правильний настрій, який залежить від психічного і від емоційного стану пацієнта. На стан пацієнта величезний вплив має ставлення до нього медпрацівника. І якщо пацієнт задоволений, наприклад, бесідою з лікарем, який його уважно вислухав у спокійній обстановці і дав йому відповідні поради, то це вже перший крок до одужання.

Основою взаємин є слово, що було відомо ще в давнину: «Лікувати треба словом, травами і ножем», вважали стародавні цілителі. В. М. Бехтерєв у 1898 р. писав: «Всякий знає, яку магічну оздоровлюючу дію може придбати одне втішне слово і, навпаки, іноді, як убивчо, в буквальному сенсі слова, діють на хворого суворий холодний вирок лікаря, який не знає або не бажає знати сили навіювання». Крилатий вислів В. М. Бехтерєва: «Якщо хворому після розмови з лікарем не стає легше - це не лікар». 
Мистецтво слова протистоїть втраті здатності до співпереживання, сприйняття болю чужого, як свого. Значення мистецтва слова в медицині розуміли ще в середні віки, коли гуманітарна освіта була для лікаря своєрідним допуском до практичної роботи. Він повинен у своїй роботі керуватися принципом: лікувати людину, а не хворобу. Мистецтво слова має унікальні цілющі, пізнавальні, виховні можливості. Сфера його вжитку практично безмежна, оскільки воно не пов'язане з жодним конкретним органом чуття, як скажімо, музика чи живопис. Воно здатне викликати і прямі образи, й асоціації, що відновлюють у пам'яті давно пережите. Розумним, тактовним словом можна підняти настрій хворого, вселити в нього бадьорість і надію на одужання і водночас необережним словом можна глибоко поранити хворого, викликати різке погіршення його здоров'я. Важливо не тільки, що говорити, а й як, навіщо, де говорити, як відреагує той, до кого звертається медичний працівник: пацієнт, його родичі, колеги і т. д. [1, 3].

Між «що сказати» і «як сказати» не існує альтернативи. І все ж принцип «не зашкодь» вимагає від лікаря бути особливо уважним, обережним у виборі слів, тим більше, коли йдеться про трагічний діагноз і потрібно зробити вибір: казати правду чи утриматися. Тут рецептів на кожен випадок немає. Одну і ту ж думку можна висловити по-різному. Одне і те ж слово люди можуть зрозуміти по-різному, залежно від свого інтелекту, особистісних якостей і т. д. Під час розмови 3 пацієнтом необхідно дотримуватися таких принципів:

- дивитися на нього з доброзичливою усмішкою і виразом обличчя показувати свою зацікавленість;

- використовувати відповідну позу;

- хитати головою на знак згоди, застосовувати повторення, вигуки, уточнення.

У розмові з хворим неприпустимі байдужість, пасивність, млявість. Хворий повинен відчувати, що

\section{ЛITЕРАТУРА}

1. Касевич Н. М. Медсестринська етика і деонтологія : підручник / Н. М. Касевич. - 3-тє вид., випр. - К. : ВСВ «Медицина», 2013. - 200 с.

2. Золотухін Г. О. Фахова мова медика : підручник / Г. О. Золотухін, Н. П. Литвиненко, Н. В. Місник. - К. : Здоров'я, 2002. - 392 с. його правильно розуміють, що медичний працівник ставиться до нього з щирим інтересом. Необхідно сконцентрувати увагу на пацієнтові, незважаючи на власні упередження, стурбованість. Необхідно вміти слухати пацієнта. Основні принципи вміння слухати:

- поставитися до пацієнта з повною повагою, не перебивати його запитаннями чи коментарями;

- дати пацієнту зрозуміти, що ви зацікавлені тим, про що він розповідає;

- намагатися зрозуміти головну думку розповіді;

- звернути увагу на те, як говорить пацієнт;

- намагатися сприймати інформацію, незважаючи на ставлення до пацієнта;

- спробувати розпізнати, про що людина хоче говорити;

- намагатися керувати своїми емоціями;

- намагатися зважити факти;

- виявляти до пацієнта повагу, турботу, інтерес, прагнути щиро зрозуміти поведінку пацієнта.

Висновки. Медичний працівник повинен володіти культурою мови. Щоб добре говорити, необхідно насамперед правильно думати. Лікар або медсестра, які «спотикаються» на кожному слові, вживають жаргонні слова та вирази, викликають недовіру і неприязнь. Деонтологічні вимоги до культури слова полягають в тому, що медичний працівник повинен вміти: розповісти хворому про хворобу та ії лікування; заспокоїти і підбадьорити хворого; використовувати слово як важливий фактор психотерапії; вживати слово так, щоб воно стало свідченням загальної та медичної культури; переконати хворого в необхідності того чи іншого лікування; терпляче мовчати, коли цього вимагають інтереси хворого; не позбавляти хворого надії на одужання; володіти собою в усіх ситуаціях. Отже, ніколи не треба забувати про «вічні питання», що стоять між тим, хто надягнув білий халат, і тим, хто звернувся до нього за допомогою.

3. Головін А. О. Основи соціальної медицини: конспект лекцій [Електронний ресурс] / А. О. Головін. - Режим доступу : ukrdoc.com.ua/text/5531/index-1.html

Отримано 05.10.16 